\title{
Increased water use efficiency does not prevent growth decline of Pinus canariensis in a semi-arid treeline ecotone in Tenerife, Canary Islands (Spain)
}

\author{
Patricia Brito $^{1}$ - Thorsten E. E. Grams ${ }^{2}$. Rainer Matysssek ${ }^{2}$ • Maria S. Jimenez ${ }^{1}$. \\ Agueda M. Gonzalez-Rodríguez ${ }^{1} \cdot$ Walter Oberhuber $^{3} \cdot$ Gerhard Wieser $^{4}$
}

Received: 18 March 2016 / Accepted: 17 May 2016/Published online: 7 June 2016

(C) The Author(s) 2016. This article is published with open access at Springerlink.com

\begin{abstract}
- Key message Intrinsic water use efficiency of Pinus canariensis (Sweet ex Spreng.) growing at a semi-arid treeline has increased during the past 37 years. Tree ring width by contrast has declined, likely caused by reduced stomatal conductance due to increasing aridity.

- Context Rising atmospheric $\mathrm{CO}_{2}$ concentration $\left(C_{a}\right)$ has been related to tree growth enhancement accompanied by increasing intrinsic water use efficiency (iWUE). Nevertheless,

\section{Handling Editor: Erwin Dreyer}

Contribution of the co-authors $\mathrm{P}$. Brito performed all experimental work and co-wrote the manuscript. T.E.E. Grams and R. Mayssek supervised the work on isotope analysis and co-worked in paper writing. M.S. Jimenez and A.M. Gonzalez-Rodríguez participated in data interpretation and provided editorial advice. W Oberhuber analyzed tree ring data and helped with data processing and statistics with respect to tree growth. G. Wieser participated in data interpretation, paper writing, and coordinated the project.
\end{abstract}

Electronic supplementary material The online version of this article (doi:10.1007/s13595-016-0562-5) contains supplementary material, which is available to authorized users.

Gerhard Wieser

Gerhard.wieser@uibk.ac.at

1 Department of Botany, Ecology and Plant Physiology, Universidad de La Laguna (ULL), C/Astrofísico Francisco Sánchez s/n, E-38207 La Laguna, Tenerife, Spain

2 Ecophysiology of Plants, Department of Ecology and Ecosystem Management, Technische Universität München, Von-Carlowitz-Platz 2, 85354 Freising, Germany

3 Institute of Botany, Leopold-Franzens-Universität Innsbruck, Sternwartestraße 15, 6020 Innsbruck, Austria

4 Department of Alpine Timberline Ecophysiology, Federal Research and Training Centre for Forests, Natural Hazards and Landscape (BFW), Rennweg 1, A-6020 Innsbruck, Austria the extent of rising $C_{a}$ on long-term changes in iWUE and growth has remained poorly understood to date in Mediterranean treeline ecosystems.

- Aims This study aimed to examine radial growth and physiological responses of $P$. canariensis in relation to rising $C_{a}$ and increasing aridity at treeline in Tenerife, Canary Islands, Spain. - Methods We evaluated temporal changes in secondary growth (tree ring width; TRW) and tree ring stable C isotope signature for assessing iWUE from 1975 through 2011.

- Results Precipitation was the main factor controlling secondary growth. Over the last 36 years $P$. canariensis showed a decline in TRW at enhanced iWUE, likely caused by reduced stomatal conductance due to increasing aridity.

- Conclusion Our results indicate that increasing aridity has overridden the potential $\mathrm{CO}_{2}$ fertilization on tree growth of $P$. canariensis at its upper distribution limit.

Keywords Climate change · Mediterranean climate ·

Drought $\cdot$ Stable carbon isotope $\cdot$ Canary island pine $\cdot$ Treeline

\section{Introduction}

The current rising atmospheric $\mathrm{CO}_{2}$ concentration $\left(C_{a}\right)$ is a central driver of climate change leading to substantial increase in temperature and altered annual precipitation patterns (Körner 2000). $C_{a}$ has increased from $303 \mu \mathrm{mol} \mathrm{mol}{ }^{-1}$ in 1920 (McCarroll and Loader 2004) to $391 \mu^{m o l ~ m o l}{ }^{-1}$ in 2011 (IPCC 2013). Increased $C_{a}$ may stimulate plant growth by reduced water loss upon stomatal closure and enhanced photosynthesis (Morgan et al. 2004; Norby et al. 2005). Consequently, intrinsic water use efficiency (iWUE), being the ratio of net carbon gain $(A)$ versus leaf conductance for water vapor $\left(g_{\mathrm{w}}\right)$, should increase (Farquhar et al. 1989). iWUE can be inferred from stable carbon isotope signature 
in tree ring wood or cellulose (McCarroll and Loader 2004). Only few studies have integrated long-term trends in climate, $\mathrm{C}_{\mathrm{a}}$, iWUE, and growth (Linares et al. 2009; Linares and Camarero 2012; Granda et al. 2014; Liu et al. 2014). Peñuelas et al. (2011) listed 47 studies related to changes in tree ringderived iWUE and/or growth of mature trees growing in tropical, arid, Mediterranean, temperate, and boreal biomes, although only seven studies had analyzed iWUE together with growth. These latter studies implied that the observed increase in $C_{a}$ and iWUE did not translate into tree growth enhancement (Peñuelas et al. 2011), suggesting other factors such as warming-related drought to override potential benefits of rising $C_{a}$ (Silva and Anand 2013; Levesque et al. 2014; Wu et al. 2014).

Mediterranean forest ecosystems are expected to drastically modify gas exchange and tree growth under rising $C_{a}$ (Huang et al. 2007; Linares and Camarero 2012; Granda et al. 2014), while drought impact is likely to intensify (Sarris et al. 2013). For the upcoming three decades, modeling predicts increase in surface air temperature by $1{ }^{\circ} \mathrm{C}$ and decrease in soil water availability by 15 to $20 \%$ for Mediterranean ecosystems (Sabaté et al. 2002; IPCC 2013), as precipitation may decline by more than $30 \%$ (Giorgi 2006; Somot et al. 2008). Evapotranspiration is expected to increase so that soils may dry, affecting resource acquisition for growth and reproduction (Durante et al. 2009).

Contrasting tree-species specific growth responses to climate change have been reported for continental Mediterranean forest trees. While some studies reported on growth enhancement in response to increasing $C_{a}$ (Rathgeber et al. 2000; Kuotavas 2008; Linares et al. 2009), other studies show declining growth trends at increasing $C_{a}$ and iWUE (Tognetti et al. 2000; Maseyk et al. 2011). Such inconsistency may arise from species-related peculiarities in growth and iWUE adjustments, linked to long-term acclimations to increasing $C_{a}$ or additional competing factors such as drought stress limiting the expected $\mathrm{CO}_{2}$-induced growth enhancement (Linares and Camarero 2012; Granda et al. 2014).

In the present study, we used tree ring width and stable $\mathrm{C}$ isotope analysis to evaluate the effects of rising $C_{a}$ and drought on growth and iWUE of Pinus canariensis (Sweet ex Spreng.) at the semi-arid treeline in Tenerife, Canary Islands, Spain. At present, no other tree species can compete with P. canariensis an endemic conifer of the Canary Archipelago, which is well adapted to xeric conditions exemplified by xenomorphic needles (Grill et al. 2004) and tap roots extending down to $15 \mathrm{~m}$ belowground (Luis et al. 2005; Climent et al. 2007). Our specific objective were (1) to determine the main limiting climatic factor for radial growth of $P$. canariensis at its upper distribution limit and (2) to test if rising atmospheric $\mathrm{CO}_{2}$ concentrations and changing environmental conditions (temperature and precipitation) at the semiarid treeline of Tenerife have caused changes in tree growth and iWUE during the past 37 years (1975-2011).

\section{Material and methods}

\subsection{Study site and climate data}

The study was conducted in a reforested even-aged P. canariensis forest growing at treeline $(2070 \mathrm{~m}$ a.s.l.) in Las Cañadas near the Visitors Centre (El Portillo) of Teide National Park ( $\left.28^{\circ} 18^{\prime} 21.5^{\prime \prime} \mathrm{N}, 16^{\circ} 34^{\prime} 5.8^{\prime \prime} \mathrm{W}\right)$, Tenerife, Canary Islands, Spain. In Las Cañadas, the treeline is formed by sharp line of isolated upright $P$. canariensis trees, and seedling establishment is severely impeded due to topsoil desiccation for about 5 months during the dry summer and frequent night frosts during the winter (Höllermann 1978; Srutek et al. 2002; Wieser et al. 2016). In 2011, the trees were 61-years old. This avoided possible age-dependent differences in growthclimate relationships, which may occur with trees of diverse ages (Carrer and Urbinati 2004).

The climate is typically semi-arid Mediterranean, with an alternation of a warm and dry period from June to September and a cold and wet period from October to May. During the period 1921-2011, mean annual precipitation was $466 \mathrm{~mm}$, with $95 \%$ falling during the cold and wet season and almost no rain in summer. Mean annual temperature was $9.7^{\circ} \mathrm{C}$, with summer maxima of up to $30.5^{\circ} \mathrm{C}$ and winter minima down to $-9.8{ }^{\circ} \mathrm{C}$. Temperature and precipitation data (annual and monthly means or sums) were obtained from the Izaña weather station, $5 \mathrm{~km}$ east of the study site $\left(28^{\circ} 18^{\prime} 21.5^{\prime \prime} \mathrm{N}, 16^{\circ} 30^{\prime}\right.$ $35^{\prime \prime} \mathrm{W} ; 2367 \mathrm{~m}$ a.s.l.; http://izana.aemet.es/) for the period 1974-2011. We also calculated an aridity index (AI) as precipitation divided by (temperature +10 ) following De Martonne (1926) for the study years, where lower AI values correspond to higher aridity.

The geological substrate is of volcanic origin (basalt), and the soil is classified as a Leptosol, a soil type typical for dry regions at high elevations in Tenerife (Arbelo et al. 2009). The water holding capacity of the topsoil $(5-35 \mathrm{~cm}$ depth) at saturation $(-0.001 \mathrm{MPa})$ is $0.46 \mathrm{~m}^{3} \mathrm{~m}^{-3}$, and the corresponding values for field capacity $(-0.033 \mathrm{MPa})$ and the wilting point $(-1.5 \mathrm{MPa}$; sensu Blume et al. 2010) are 0.23 and $0.09 \mathrm{~m}^{3} \mathrm{~m}^{-3}$, respectively (Brito et al. 2014). Due to frequent precipitation during the cold and wet season, soil water potential at $25-30 \mathrm{~cm}$ soil depth rarely drops below $-0.02 \mathrm{MPa}$ and remains close to the wilting point throughout the dry summer (Brito et al. 2014).

\subsection{Sampling and dendrochronological procedure}

Dendrochronological methods were used to assess changes in stem radial growth. In fall 2011, we sampled five trees which were previously used for stem $\mathrm{CO}_{2}$ efflux and sap flow measurements (Brito et al. 2010, 2015). Two cores per tree (S and $\mathrm{W}$ exposure) were taken at diameter at breast height (DBH) using a 5-mm-diameter increment borer. For contrast 
enhancement of tree ring boundaries, the cores were dried in the laboratory, non-permanently mounted on a holder, and the surface was prepared with a razor blade. Ring widths were measured to the nearest $1 \mu \mathrm{m}$ using a reflecting microscope (Olympus SZ61) and the software package TSAP WIN Scientific. Tree ring chronologies of the single cores were plotted and cross-dated visually and statistically, respectively. The TSAP software was used for statistically cross-dating by assessing the Gleichläufigkeit (=synchronicity between time series). Gleichläufigkeit is the percent agreement in the signs of the first difference of time series data (Eckstein and Bauch 1969). Agreement was also quantified parametrically using the product-moment correlation coefficient, which in turn was adjusted for the amount of overlap between tree ring series using the standard $t$ statistic, whereby the threshold for acceptable statistical quality was suggested to be 3.5 (Baillie and Pilcher 1973). Ring widths of both cores from each sample tree were averaged, and the quality of the chronologies was evaluated with the ARSTAN software (Cook 1987; Holmes 1994) through calculation of the Expressed Population Signal (EPS; Wigley et al. 1984).

\subsection{Stable isotope analysis, ${ }^{13} \mathrm{C}$ discrimination, and intrinsic water use efficiency}

$\delta^{13} C$ analyses for the years $1975-2011$ were performed on same cores as used for TRW assessment. Preventing juvenile effects on isotopic tree ring signatures (Heaton 1999; but see McDowell et al. 2011), only the most recent 37 years (19752011) of ring formation were sampled. Annual rings (early wood plus late wood) were cut exactly at ring boundaries by use of a scalpel and a reflecting microscope (Wild 308700). For each of the five study trees two samples per tree ring were pooled and homogenized with a swing mill (Retsch MM301, Retsch Haan, Germany). In a subsample, we compared isotope signatures in bulk wood with those in cellulose for determining the necessity of cellulose extraction in our study trees. Cellulose extraction was performed using a modified version of the method of Brendel et al. (2000.). This methodological comparison corroborated a significant correlation $\left(R^{2}=0.93\right.$; $P<0.001$; Fig. 1). On average, $\delta^{13} \mathrm{C}$ in cellulose was higher by $1.4 \pm 0.1 \%$ o than in bulk wood, and differences between wood and cellulose $\delta^{13} \mathrm{C}$ were almost constant amongst trees and tree ring age (see Online Resource Fig. OR1) as reported earlier for other conifer species (Borella and Leuenberger 1998; Jaggi et al. 2002; Sohn et al. 2013; Weigt et al. 2015). Therefore, we corrected the isotope offset of $1.4 \%$ between cellulose and bulk wood, as we used bulk wood instead of extracted cellulose for our isotope analysis (c.f. also Saurer and Siegwolf 2007).

For analyzing $\delta^{13} C, 2.0 \pm 0.02 \mathrm{mg}$ of homogenized samples were weighed into tin capsules $(3.5 \times 5 \mathrm{~mm}$, IVA Analysentechnik e. K., Meerbush, Germany) and combusted

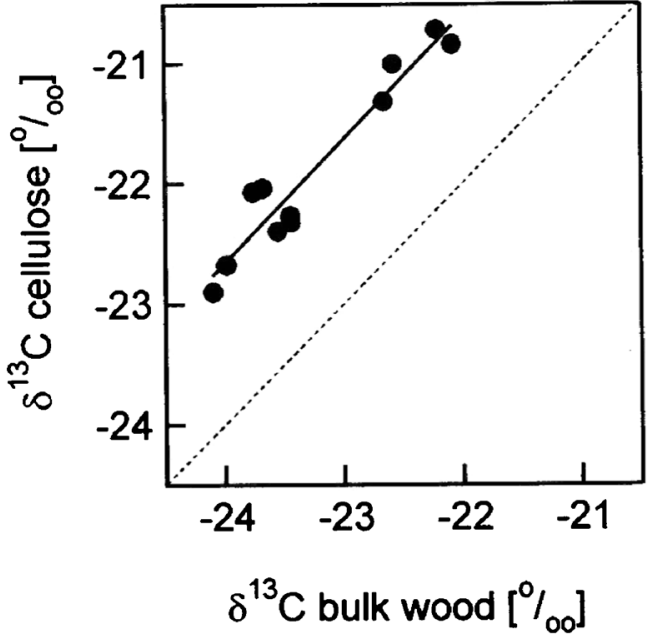

Fig. 1 Comparison of $\delta^{13} C$ in bulk wood and cellulose of annual growth rings of $P$. canariensis. Points were fit by linear regression analysis: $y=1.04 \times+2.14 ; R^{2}=0.93 ; P<0.001$. The dashed line reflects the oneto-one line for comparison

to $\mathrm{CO}_{2}$ in an elemental analyzer (Eurovector EA3000) connected to an isotope ratio mass spectrometer (Isoprime, Elementar, Hanau, Germany). The isotope signature is expressed in the delta $(\delta)$ notation in parts per thousand relative to the Vienna Pee-Dee Belemnite (V-PDB) standard:

$\delta_{\text {sample }}=\left(R_{\text {sample }} / R_{\text {standard }}-1\right) * 1000$

where $R_{\text {sample }}$ and $R_{\text {standard }}$ represent the ${ }^{13} \mathrm{C} /{ }^{12} \mathrm{C}$ ratios of the sample and the V-PDB standard, respectively. The analytical precision was $<0.12 \%$ (expressed as standard deviation of an internal laboratory standard using identical sample mass).Tree ring specific $\delta^{13} C$ was corrected for the progressive decline in atmospheric $\delta^{13} \mathrm{C}$ through calculating ${ }^{13} \mathrm{C}$ discrimination $\left(\Delta^{13} C\right)$ :

$\Delta^{13} C=\left(\delta^{13} C_{\text {atm }}-\delta^{13} C_{\text {tring }}\right) /\left(1+\delta^{13} C_{\text {tring }} / 1000\right)$

where $\delta^{13} C_{\text {atm }}$ and $\delta^{13} C_{\text {tring }}$ are the ${ }^{13} \mathrm{C} /{ }^{12} \mathrm{C}$ ratios in atmospheric $\mathrm{CO}_{2}$ and tree rings, respectively. $\Delta^{13} \mathrm{C}$ can also be calculated as follows in order to relate $\Delta^{13} C$ with physiological responses:

$\Delta^{13} C=a+(b-a) * C_{i} / C_{a}$

where $a(=4.4 \%)$ refers to the slower diffusivity of ${ }^{13} \mathrm{CO}_{2}$ relative to ${ }^{12} \mathrm{CO}_{2}$ in air, $b(=27 \%)$ is the isotopic fractionation caused by enzymatic $\mathrm{C}$ fixation, and $C_{i}$ and $C_{a}$ are the $\mathrm{CO}_{2}$ concentrations in the intercellular space of the needles and the atmosphere, respectively. The long-term trend in $\delta^{13} C_{a t m}$ from 1980 to 2011 was obtained from direct atmospheric measurements (www.scrippsco2.ucsd.edu) and extrapolated for the 
years 1975 through 1979. $C_{a}$ was obtained from published data (http://cdiac.ornl.gov/trends/co2/sio-mlo.html; 19752011) and regional data back to 1991 at Izaña taken from the Earth System Research Laboratory website (www.esrl. noaa.gov/gmd/about/aboutgmd.html; code-IZO). It should be noted that $\Delta^{13} C$ is determined by the ratio of chloroplast to the ambient $\mathrm{CO}_{2}$ mole fraction $\left(C_{c} / C_{a}\right)$ rather than $C_{i} / C_{a}$, as used in Eq. 3, making here the calculated value sensitive to mesophyll conductance ( $g_{m}$; Seibt et al. 2008). The latter varies in accordance to changes in environmental conditions such as temperature, irradiance, water, and $\mathrm{CO}_{2}$ availability (Flexas et al. 2008). Consequently, using $C_{a}$ may be problematic if $g_{m}$ to $\mathrm{CO}_{2}$ is not constant (Seibt et al. 2008). However, as information on mesophyll conductance of $P$. canariensis is not available and published means of $g_{m}$ would not improve results (Cernusak et al. 2013), we chose using the simplified linear model of Farquhar et al. (1982). Hence, intrinsic water use efficiency (iWUE), i.e., the ratio of the net carbon gain $(A)$ versus leaf conductance for water vapor $\left(g_{\mathrm{w}}\right)$, was calculated as follows:

$\mathrm{iWUE}=A / g_{w}=C_{a}\left(b-\Delta^{13} C\right) /\left(1.6^{*}(b-a)\right)$

where 1.6 is the ratio between the diffusivities of water vapor and $\mathrm{CO}_{2}$ in air.

\subsection{Data analysis}

We assessed Pearson's correlations for assessing the climatic impact on the tree ring variables TRW and $\Delta^{13} \mathrm{C}$ throughout the study period (1975-2011). These statistical analyses were based on seasonal and annual calculations of mean air temperature $\left({ }^{\circ} \mathrm{C}\right)$, total precipitation $(\mathrm{mm})$, and AI for the prior and current growing year using the SPSS 16 software package (SPSS Inc., Chicago, USA). A probability level of $P<0.05$ was considered as statistically significant. As suggested by Sarris et al. (2013) we did not remove any age-related trend from our tree ring chronologies by conventional detrending procedures, thus, avoiding the risk of removing any environmental signal or trend captured by our tree ring series.

\section{Results}

\subsection{Inter-annual trends in environmental conditions, TRW, and $\Delta^{13} \mathrm{C}$}

Climate analysis reveal that at our treeline site mean air temperature had increased by $0.3{ }^{\circ} \mathrm{C}$ per decade during the period 1975-2011 (Fig. 2a), in particular during spring and summer (see Online Resource Table OR1). Precipitation by contrast declined by $77 \mathrm{~mm}$ per decade (Fig. 2b), especially during spring (see Online Resource Table OR1). On an annual scale,

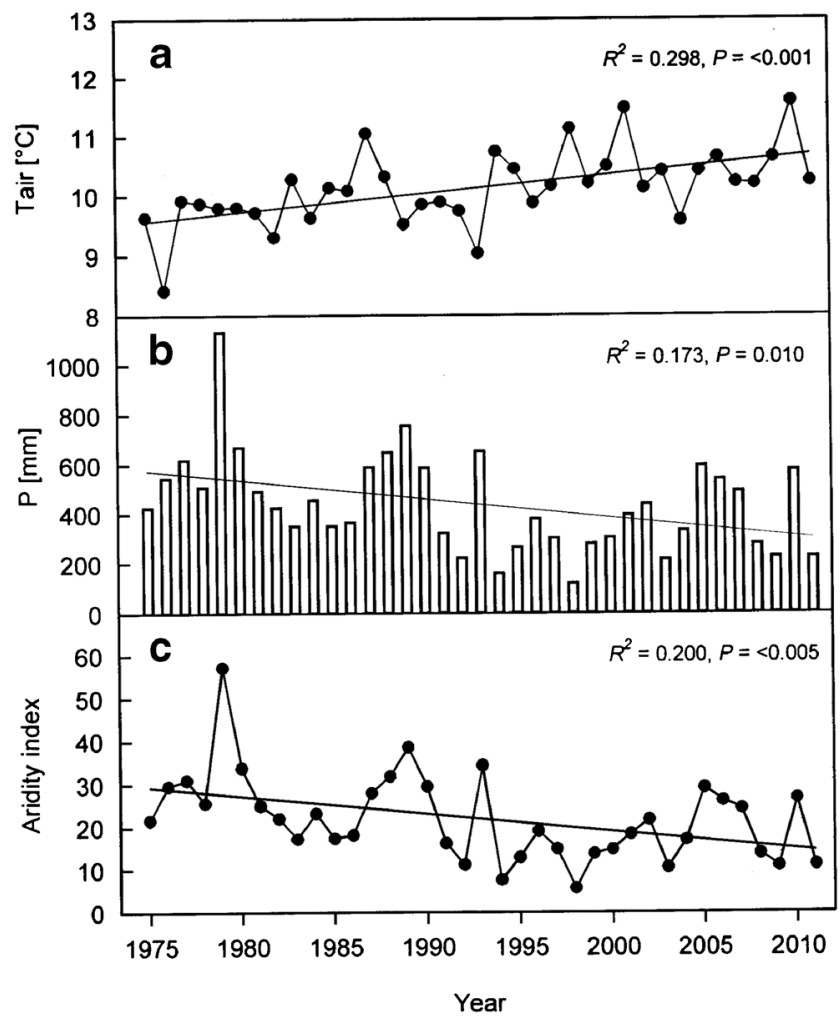

Fig. 2 Temporal variation in a mean annual air temperature (Tair), b total annual precipitation (P), and $\mathbf{c}$ the aridity index during the period 1975 throughout 2011. Regression analysis: mean annual air temperature: $y=0.031 \times-52.6, R^{2}=0.298, P<0.001$; total annual precipitation: $y=-7.6 \times+15,672, R^{2}=0.173, P=0.01$; aridity index: $y=-0.42 \times+$ $856.5 ; R^{2}=0.20, P=0.005$

increasing temperature coupled with a decrease in precipitation patterns therefore also caused a decline in the aridity index of 4.1 per decade (Fig. 2c; Online Resource Table OR1).

The five study trees were even-aged and the mean ring width was $2.68 \pm 0.17 \mathrm{~mm}$. Synchronicity ("Gleichläufigkeit") between the ring width series reached values $>73 \%$, and $t$ values $>5.3$ (see Online Resource Table OR2). The expressed population signal (EPS) was 0.91 , suggesting adequate replications and a strong common climate signal in our treeline chronology.

We detected a significant decline in TRW from 1975 to $2011(P=0.002)$ reaching a minimum in 2008 (Fig. 3a). Tree ring $\Delta^{13} C$ did not vary considerably during the past 37 years. $\Delta^{13} C$ averaged $14.2 \pm 0.3 \%$ and varied between $14.8 \pm 0.2 \%$ in 1976 and $13.2 \pm 0.6 \%$ in 1984 (Fig. 3b).

\subsection{Climate growth relationships}

Pearson's correlations revealed strong links between climatic parameters and the TRW chronology (Table 1; Online Resource Table OR3 and OR4). The main factor controlling TRW was precipitation (Table 1). At a seasonal scale, the 


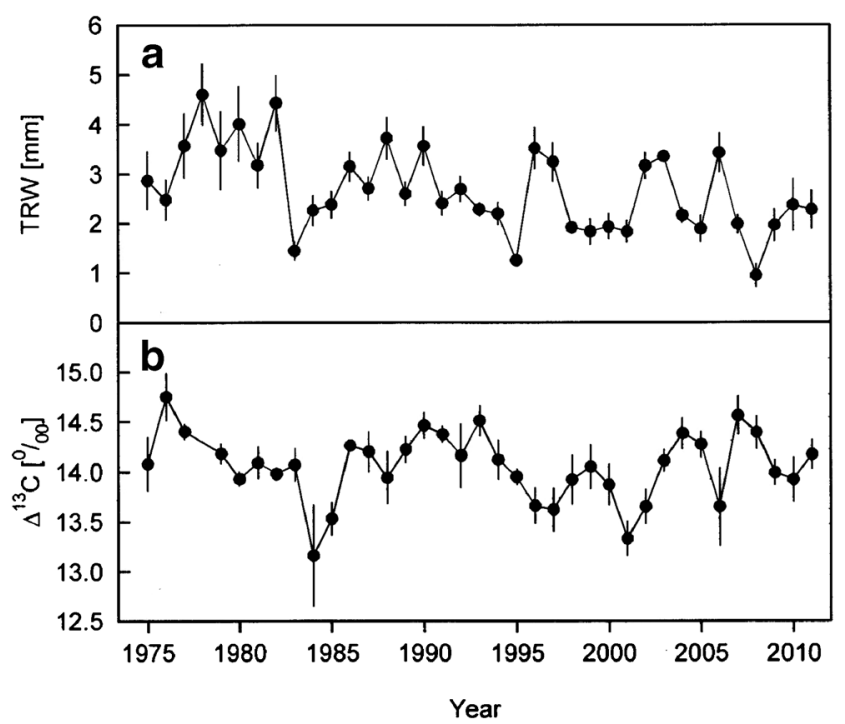

Fig. 3 Chronologies of a tree ring width (TRW) and b $\Delta^{13} \mathrm{C}$ of P. canariensis from 1975 throughout 2011. Values are the mean $\pm \mathrm{SE}$ of five trees

TRW was significantly favored by winter (previous Dec-Feb; $r=0.396, P=0.015)$ and spring $(r=0.387, P=0.018)$ precipitation (Table 1). Interestingly, rainfall of the previous fall had no significant effect on TRW. Correlations between TRW and precipitation, however, improved when we extended the integration period from seasonal to longer time scales, covering (1) winter and spring $(r=0.511, P=0.009)$, (2) calendar year

Table 1 Pearson's correlation coefficients calculated between tree ring chronologies (tree ring width, TRW; and ${ }^{13} \mathrm{C}$ discrimination, $\Delta{ }^{13} \mathrm{C}$ ) and integrated periods of precipitation for the period 1975-2011. (-1) indicates the season of the previous year. Spring: March-May, Summer: June-August, Autumn: September-November, Winter: previous year December-February, Calendar year: January-December, hydrological year: October $(-1)$-September

\begin{tabular}{lll}
\hline Season & TRW & $\Delta^{13} C$ \\
\hline Autumn (-1) & 0.303 & -0.043 \\
Winter & $0.396^{*}$ & 0.038 \\
Spring & $0.387^{*}$ & $0.351^{*}$ \\
Summer & -0.147 & 0.153 \\
Autumn & -0.057 & -0.028 \\
Winter and spring & $0.511^{* *}$ & 0.191 \\
Calendar year & $0.419^{* *}$ & 0.180 \\
Hydrological year & $0.579^{* * *}$ & 0.160 \\
Multi-year & & \\
2 years & $0.560^{* * *}$ & 0.198 \\
3 years & $0.502^{* *}$ & 0.295 \\
4 years & $0.513^{* *}$ & 0.327 \\
\hline
\end{tabular}

Significant correlations are set in italics $(* P<0.05, * * P<0.01$, $* * * P<0.001)$ $(r=0.419, P=0.010),(3)$ hydrological year $(r=0.579$, $P<0.001$ ), and (4) multiple year precipitation (all $r<0.502$, and $P<0.020$ ), respectively (Table 1). Spring precipitation also significantly favored $\Delta^{13} C(r=0.351, P=0.036$; Table 1$)$.

Pearson's correlation indicated a significantly negative effect of summer temperature on TRW $(r=-0.424, P=0.009)$, as well as significantly negative effects of autumn $(r=-0.444$, $P=0.007)$ and calendar year temperature $(r=-0.400$, $P=0.016$ ) on $\Delta^{13} C$ (Online resource Table OR3). Pearson's correlation also indicated a significant positive effect of winter ( $r=0.378, P=0.021)$, spring $(r=0.381, P=0.020)$, calendar year $(r=0.426, P=0.009)$, and hydrological year $(r=0.579$, $P<0.001$ ) aridity index (AI; where lower values correspond to a higher aridity) on TRW, and of spring AI ( $r=0.358$, $P=0.032)$ on $\Delta^{13} C$ (Online Resource Table OR4).

\subsection{Inter-annual trends of $C_{a}, C_{i}, C_{i} / C_{a}$, and iWUE}

Global atmospheric $\mathrm{CO}_{2}$ concentration $\left(C_{a}\right)$ increased from $331 \mu \mathrm{mol} \mathrm{mol}{ }^{-1}$ in 1975 to $392 \mu \mathrm{mol} \mathrm{mol}^{-1}$ in 2011 (Fig. 4a), being in agreement with local $C_{a}$ increase as recorded at the Izaña Observatory from 1991 throughout 2011 $\left(R^{2}=0.99 ; P<0.001\right.$; see Online Resource Fig. OR2). Paralleling atmospheric $\mathrm{CO}_{2}$ enhancement, tree ring-derived intercellular $\mathrm{CO}_{2}$ concentration $\left(C_{i}\right)$ increased significantly $\left(R^{2}=0.619, P<0.001\right)$ from 1975 through 2011 from 142 to $169 \mu \mathrm{mol} \mathrm{mol}^{-1}$ (Fig. 4a). The trend of $C_{i} / C_{a}$ revealed no

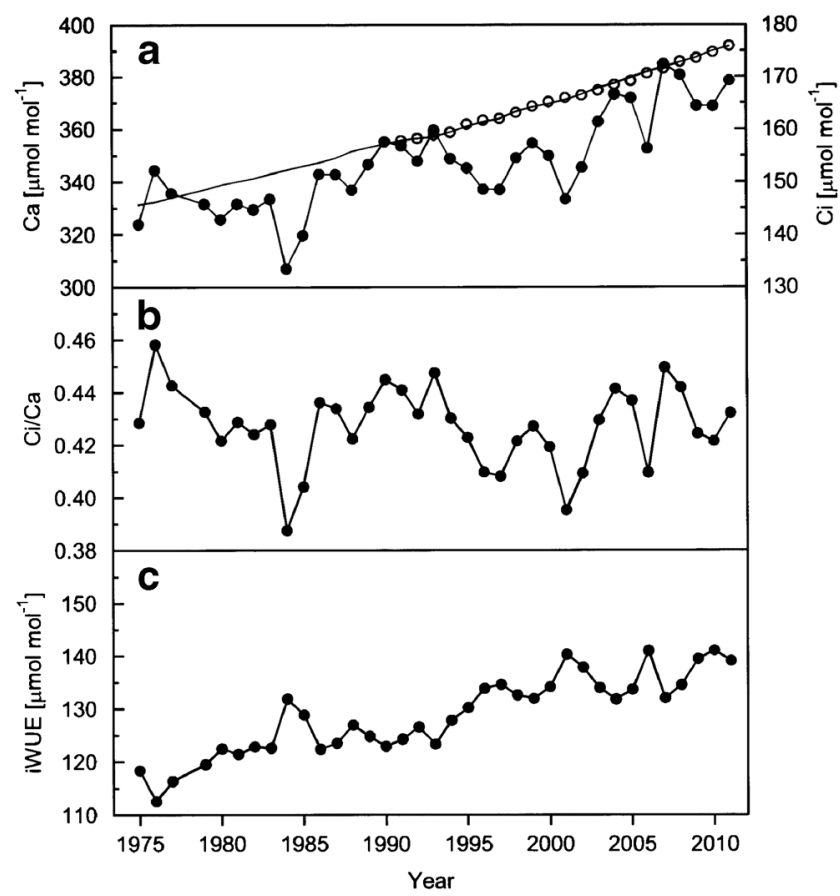

Fig. 4 Temporal variation in a global (thin line) and local (open circles) atmospheric $\mathrm{CO}_{2}$ concentration $\left(C_{a}\right)$, internal $\mathrm{CO}_{2}$ concentration $\left(C_{i}\right.$; solid circles); $\mathbf{b} C_{i} / C_{a}$, and $\mathbf{c}$ intrinsic water use efficiency (iWUE) 
significant trend over the past 36 years $\left(R^{2}=0.009, P=0.58\right)$, with $C_{i} / C_{a}$ averaging $0.43 \pm 0.01$ (Fig. $\left.4 \mathrm{~b}\right)$. P. canariensis significantly increased their iWUE $\left(R^{2}=0.80 ; P<0.001\right)$ from 1975 through 2011 (Fig. 4c).

\section{Discussion}

Our results indicate a warming trend at our treeline site for the period 1975-2011, coupled with reduced precipitation, and therefore also increasing aridity (Fig. 2; Online Resource Table OR1), which is in agreement with recent climate change models forecasting similar trends towards 2100 (IPCC 2013). Although we only sampled five even-aged trees, the correlations between the single TRW chronologies were highly significant (Online Resource Table OR2) and the EPS was 0.91. Thus, the EPS for our TRW chronology is within the range of 0.84 and 0.98 estimated for 12 young $P$. canariensis stands of growing between 1120 and $1930 \mathrm{~m}$ a.s.l. on the Cordillera Dorsal of Tenerife (Rozas et al. 2013). Our estimated EPS of 0.91 is also considerably above the threshold of 0.85 suggested by Wigley et al. (1984) and thus suggests adequate replications and a strong common climate signal in our treeline chronology with respect to radial growth and the $\delta^{13} C$ signal (c.f. also Borella and Leuenberger 1998 and Levesque et al. 2014). Furthermore, there is also evidence that young $P$. canariensis trees are more sensitive to limiting climatic conditions than older ones (Rozas et al. 2013), as has also been reported for the Mediterranean conifers Juniperus thurifera (Rozas et al. 2009) and Pinus pinaster (Vieira et al. 2009). In addition, young $P$. canariensis trees have no missing rings, and thus contrasting with mature trees, where missing tree rings are a major limitation for the successful dating of tree ring series (Jonsson et al. 2002).

Stem radial growth variability was mainly controlled by precipitation. The positive responses of TRW to winter, spring, calendar year, and especially to hydrological year and multiple years precipitation (Table 1) are in line with findings from other leeward $P$. canariensis plantations established between 1950 and 1970 between 1130 and $2100 \mathrm{~m}$ a.s.l. (Rozas et al. 2013) and indicates that water availability constraints tree growth at treeline in Tenerife (Gieger and Leuschner 2004). The beneficial effect of winter, spring, and hydrological year precipitation is due to a pronounced water deficit at treeline, as $95 \%$ of the annual precipitation falls during the cold and wet season (October-May). The beneficial effect of hydrological year and multiple year precipitation on TRW of $P$. canariensis (Table 1; Jonsson et al. 2002) supports the idea that $P$. canariensis is able to tap water from deeper soil layers originating from years prior the growing season (Brito et al. 2015) as has also been documented for Pinus halepensis subsp. brutia at a dry low elevation site at Samos, Greece (Sarris et al. 2013). Indeed, net primary production at our treeline site has been shown to be considerably higher in a hydrological moist as compared to a hydrological dry year (Wieser et al. 2016).

We also observed a negative response of TRW to warm summers (Table 1) which may be due to drought-induced stomatal closure, a loss in photosynthetic efficiency (Brito 2016) and enhanced respiratory carbon losses of aboveground woody tissues (Brito et al. 2010, 2013). Ample soil water availability and a lower evaporative demand as compared to the warm and dry summer (Brito et al. 2015) may help explain the lack of a significant response of TRW to winter and spring temperatures. The lack of any significant positive correlation between TRW and temperature may be attributed to the fact that mean annual air temperature at treeline (Fig. 2; 10.6 $\pm 0.5{ }^{\circ} \mathrm{C}$ ) is noticeably higher than the mean air temperature range of 5.5 to $7.0^{\circ} \mathrm{C}$ suggested to limit growth in continental treelines worldwide by Körner (2003, 2012). A higher temperature limit for tree growth in Mediterranean climates has also been suggested by Vieira et al. (2013).

Although radial stem increment at treeline in Tenerife terminates round mid-June (Brito et al. 2010), stem radial increment may be prolonged till late fall in hydrological moist years (Brito 2016). Under conditions of severe summer drought when stomata are completely closed (Brito et al. 2014, 2015), stem radial growth however does not extend into the peak of the dry season (Brito et al. 2010). This may help explain the lack of any significant positive correlations between climatic parameters and $\Delta^{13} C$, except for spring precipitation in Table 1 and AI (Online Resource Table OR4), the period when maximum radial growth normally takes place in P. canariensis at treeline (Brito et al. 2010; Brito 2016).

It has been shown that in dry years trees photoassimilates accumulate in Pinus brutia (Körner 2003), and recent work in drought-exposed Pinus sylvestris confirm that nonstructural carbohydrates during periods when cambial activity is close to zero (Gruber et al. 2012), opposite to the often assumed C starvation under drought. Probably, some $\mathrm{C}$ was fixed during the dry summer (Brito 2016). As there was commonly no growth during the dry summer, these stored carbohydrates were used for late wood production in autumn when soil water availability permits growth. As we used complete tree rings (early and late wood milled together), the isotopic signal corresponding to summer drought was retained in the annual isotopic signature of the whole tree ring (c.f. also Sarris et al. 2013).

At our treeline site $P$. canariensis showed a constant $C_{i} / C_{a}$ ratio over time, leading to a moderate increase in iWUE under rising $C_{a}$ (Fig. 3). The increase in iWUE observed at our study site is within the range of rising iWUE values of about 8 to $25 \%$ reported for various Mediterranean forest trees since the 1970s (Ferrio et al. 2003; Peñuelas et al. 2011; Linares and Camarero 2012; Granda et al. 2014). Although iWUE increased over 
time (Fig. 3c), radial growth has been declining, and thus suggesting that a reduction in stomatal conductance has prevailed which however does not rule out the possibility of changes in $\mathrm{C}$ allocation patterns or postphotosynthetic processes (Voltas et al. 2013). The decline in TRW reported here for our treeline site is in agreement with recent studies showing warming-induced growth reductions in spite of increasing iWUE for a variety of tree species at dry sites in the Iberian peninsula (Peñuelas et al. 2008; Linares and Camarero 2012; Granda et al. 2014). Thus, our results suggest that a drought-induced stomatal closure resulting from increasing temperature and aridity has reduced tree transpiration at the price of reducing net assimilation rate, thus overriding the potential $\mathrm{CO}_{2}$ fertilizer effect. This could have been intensified at our treeline site by low soil water availability resulting from low soil water holding capacity of the topsoil (Brito et al. 2014).

Conversely, soil drying does not necessarily imply P. canariensis to suffer from water limitation as shown by Brito et al. (2015). Drought conditions at our study site are related to reduced winter rainfall which typically supplies more than $95 \%$ of the annual precipitation. When winter rainfall is small, tree growth is low as evidenced at our study site by low annual increment in radial growth (Brito et al. 2010). Once topsoil moisture pools are exhausted, the ability to tap water from deeper soil moisture pools determines annual growth (Brito et al. 2010), water loss (Brito et al. 2015), and hence also $g_{w}$ (Wieser et al. 2016). Moreover, remaining carbon not used for maintenance of metabolic processes during drought may be allocated into roots (Dewar et al. 1994), because during periods of drought stress $\mathrm{C}$ investments into below ground growth are of higher priority than aboveground growth (Kotzlowski and Palladry 2002) to ensure water acquisition (Saxe et al. 1998).

P. canariensis also adapts to soil drought by developing deep tap roots extending down to $15 \mathrm{~m}$ belowground (Luis et al. 2005; Climent et al. 2007) allowing trees to use soil water reserves in deep soil layers when topsoil moisture pools are exhausted (Brito et al. 2015). For the next three decades, climate change and ecophysiological models for Mediterranean ecosystems predict an increase in surface air temperature of $1{ }^{\circ} \mathrm{C}$ and a $15-20 \%$ lower soil water availability (Sabaté et al. 2002; IPCC 2013) due to a more than $30 \%$ reduction in precipitation (Giorgi 2006; Somot et al. 2008). In this case growth will primarily depend on the recharge of deep soil water pools, the latter originating from rainfall prior the current year's growth available later in the growing season. Canopy transpiration (Brito et al. 2015) data underpin the significance of deep soil water reserves on the physiological behavior of $P$. canariensis at its upper distribution limit during the dry summer (Brito 2016).

\section{Conclusions}

Our results indicate that water availability was the main factor controlling TRW of $P$. canariensis at its upper distribution limit. During the past 37 years increasing aridity reduced TRW, while iWUE increased over time. Although it may not completely be ruled out that observed changes in TRW and iWUE are at least partly due to tree aging, our findings agree with recent studies from the Iberian Peninsula (Peñuelas et al. 2008; Linares and Camarero 2012; Granda et al. 2014) indicating reduced stomatal conductance and carbon uptake under xeric conditions despite rising $C_{a}$. Finally, our study highlights the importance of deeper soil moisture pools on TRW. Therefore, a solid knowledge on precipitation patterns, soil water pools and source water utilized for tree growth (Sarris et al. 2013; Levesque et al. 2014) is essential for understanding tree response to changes in ambient $\mathrm{CO}_{2}$ concentration and water availability in semi-arid and arid environments.

Acknowledgments Open access funding provided by University of Innsbruck and Medical University of Innsbruck. The authors express their gratitude to National Park's Network for permission to work in Teide National Park. We also thank D. Morales for helpful suggestions on experimental design.

\section{Compliance with ethical standards}

Funding This work was supported by the Spanish Government [CGL2006-10210/BOS, CGL2010-21366-C04-04 MCI] and cofinanced by FEDER and Austrian Science Fund Project [FWF P 22206-B16; Transpiration of conifers in contrasting environments]. P.B. received a fellowship from "Canarian Agency for Research, Innovation and Information Society [ACIISI]" cofinanced by FEDER and a STSM Grant from Action FP0903 [Climate Change and Forest Mitigation and Adaptation in a Polluted Environment (MAFor)] to visit TUM.

Open Access This article is distributed under the terms of the Creative Commons Attribution 4.0 International License (http:// creativecommons.org/licenses/by/4.0/), which permits unrestricted use, distribution, and reproduction in any medium, provided you give appropriate credit to the original author(s) and the source, provide a link to the Creative Commons license, and indicate if changes were made.

\section{References}

Arbelo CD, Rodríguez A, Sánchez J, Notario JS, Recatalá L, Mora JL, Guerra JA, Armas CM (2009) Caracterización en Entorno SIG de los Suelos del Parque Nacional del Teide. Dinámica de Nutrientes y Carbono en los Suelos. Departamento de Edafología y Geología, Universidad de La Laguna. Proyectos de investigación en parques nacionales: 2005-2008 www.mma.es/secciones/el_ministerio/ organismos/oapn/pdf/oapn_inv_art_0503.pdf

Baillie MGL, Pilcher JR (1973) A simple cross-dating program for treering research. Tree-Ring Bull 38:35-43

Blume H-P, Brümmer GW, Horn R, Kandeler E, Kögl-Knabler I, Kretzschmar R, Stahr K, Wilke B-M (2010) Scheffer/ 
Schachtchabel: Lehrbuch der Bodenkunde. Spektrum Akademischer Verlag, Heidelberg

Borella S, Leuenberger M (1998) Reducing uncertainties in $\delta^{13} C$ analysis of tree rings: pooling, milling, and cellulose extraction. J Geophys Res 103:19519-19526

Brendel O, Iannetta PPM, Stewart D (2000) A rapid and simple method to isolate pure alpha-cellulose. Phytochem Anal 11:7-10

Brito P (2016) Challenges of living in the treeline: an ecophysiological approach to the study of plants at high elevation in Tenerife under the climate change context. Dissertation University La Laguna

Brito P, Morales D, Wieser G, Jiménez MS (2010) Spatial and seasonal variations in stem $\mathrm{CO}_{2}$ efflux of Pinus canariensis at their upper distribution limit. Trees 24:523-531

Brito P, Jiménez MS, Morales D, Wieser G (2013) Assessment of ecosystem $\mathrm{CO}_{2}$ efflux and its components in a Pinus canariensis forest at the treeline. Trees 27:999-1009

Brito P, Lorenzo JR, Gonzalez-Rodríguez AM, Morales D, Wieser G, Jiménez MS (2014) Canopy transpiration of a Pinus canariensis forest at the tree line: implications for its distribution under predicted climate warming. Eur J For Res 133:491-500

Brito P, Lorenzo JR, Gonzales Rodriguez AM, Morales D, Wieser G, Jimenez MS (2015) Canopy transpiration of a semi arid Pinus canariensis forest at a treeline ecotone in two hydrologically contrasting years. Agric For Meteorol 201:120-127

Carrer M, Urbinati C (2004) Age-dependent tree-ring growth responses to climate in Larix decidua and Pinus cembra. Ecology 85:730-740

Cernusak LA, Ubierna N, Winter K, Holtum JAM, Marshall JD, Farquhar GD (2013) Envirinmental and physiological determinants of carbon isotope discimination in terrestrial plants. New Phytol 200:950-965

Climent J, López R, Gonzalez S, Gil L (2007) El pino canario (Pinus canariensis), uns especie singular. Ecosistemas 16:80-89

Cook ER (1987) The decomposition of tree-ring series for environmental studies. Tree-Ring Bull 47:37-59

De Martonne E (1926) L'indice d'aridité. Bulletin de l'Association des Géographes Francais 9:3-5

Dewar RC, Ludlow AR, Dougherty PM (1994) Environmental influences on carbon allocation in pines. Ecol Bull 43:92-101

Durante P, Oyonarte C, Valladares F (2009) Influence of land-use types and climatic variables on seasonal patterns of NDVI in Mediterranean Iberian ecosystems. Appl Veg Sci 12:177-185

Eckstein D, Bauch J (1969) Beitrag zur Rationalisierung eines dendrochronologischen Verfahrens und zur Analyse seiner Aussagesicherheit. Forstwiss Centralbl 88:230-250

Farquhar GD, O'Leary MH, Berry JA (1982) On the relationship between carbon isotope discrimination and the intercellular carbon dioxide concentration in leaves. Aust J Plant Physiol 9:121-137

Farquhar GD, Ehleringer JR, Hubick KT (1989) Carbon isotope discrimination and photosynthesis. Annu Rev Plant Physiol 40:503-537

Ferrio JP, Florit A, Vega A, Serrano L, Voltas J (2003) Delta(13)C and tree-ring width reflect different drought responses in Quercus ilex and Pinus halepensis. Oecologia 137:512-518

Flexas J, Ribas-Carbo M, Diaz-Espejo A, Glamés J, Medrano H (2008) Mesophyll conductance to $\mathrm{CO}_{2}$ : current knowledge and future prospects. Plant Cell Environ 31:602-621

Gieger T, Leuschner C (2004) Altitudinal change in needle water relations of Pinus canariensis and possible evidence of a drought-induced alpine timberline on Mt. Teide, Tenerife. Flora 199:100-109

Giorgi F (2006) Climate change hot-spots. Geophys Res Lett 33, L08707. doi:10.1029/2006GL02573

Granda E, Rosattop DR, Camarero JJ, Voltas J, Valladares F (2014) Growth and carbon isotopes of Mediterranean trees reveal contrasting responses to increased carbon dioxide and drought. Oecologia 174:307-317

Grill D, Tausz M, Pöllinger U, Jiménez MA, Morales D (2004) Effects of drought on needle anatomy of Pinus canariensis. Flora 199:85-89
Gruber A, Pirkebner D, Florian C, Oberhuber W (2012) No evidence for depletion of carbohydrate pools in Scots pine (Pinus sylvestris) under drought stress. Plant Biol 14:1421-148

Heaton THE (1999) Spatial, species, and temporal variations in the ${ }^{13} \mathrm{C} /{ }^{12} \mathrm{C}$ ratios of $\mathrm{C}_{3}$ plants: implications for palaeodiet studies. $\mathrm{J}$ Archeol Sci 26:637-649

Höllermann PW (1978) Geoecological aspects of the upper timberline in Tenerife, Canary Islands. Arct Alp Res 10:365-382

Holmes RL (1994) Dendrochronology program library user's manual. Laboratory of Tree-Ring Research University of Arizona, Tucson, USA

Huang JG, Bergeron Y, Denneler B, Berninger F, Tardif J (2007) Response of forest trees to increased atmospheric $\mathrm{CO}_{2}$. Crit Rev Plant Sci 26:265-283

Intergovernmental Panel on Climate Change (IPCC) (2013) Climate change 2013: the physical science basis. Cambridge University Press, Cambridge

Jaggi M, Saurer M, Fuhrer J, Siegwolf R (2002) The relationship between the stable carbon isotope composition of needle bulk material, starch, and tree rings in Picea abies. Oecologia 131:325-332

Jonsson S, Gunnarson B, Criado C (2002) Drought is the major limiting factor for tree-ring growth of high-altitude Canary Island pines on Tenerife. Geogr Ann 84:51-71

Körner C (2000) Biosphere responses to $\mathrm{CO}_{2}$ enrichment. Ecol Appl 10 : $1590-1619$

Körner C (2003) Carbon limitation in tree. J Ecol 9:4-17

Körner C (2012) Alpine treelines. Functional ecology of the global high elevation limits. Springer, Basel

Kotzlowski T, Palladry S (2002) Acclimation and adaptive responses of woody plants to environmental stress. Bot Rev 68:270-334

Kuotavas A (2008) Late 20th century growth acceleration in Greek firs (Abies cephalonica) from Cephalonia Island, Greece: a $\mathrm{CO}_{2}$ fertilization effect? Dendrochronologia 26:13-19

Levesque M, Siegwolf R, Saurer M, Eilmann B, Brang P, Bugmann H, Rigling A (2014) Drought response of five conifer species under contrasting water availability suggests high vulnerability of Norway spruce and European larch. Glob Chang Biol 19:3184 3199

Linares JC, Camarero JJ (2012) From pattern to process: linking intrinsic water-use efficiency to drought-induced forest decline. Glob Chang Biol 18:1000-1015

Linares JC, Delgado-Huertas A, Julio Camarero J, Merino J, Carreira JA (2009) Competition and drought limit the response of water-use efficiency to rising atmospheric carbon dioxide in the Mediterranean fir Abies pinsapo. Oecologia 161:611-624

Liu X, Wang W, Xu G, Zeng X, Wu G, Zhang X, Qin D (2014) Tree growth and intrinsic water-use efficiency of inland riparian forests in northwestern China: evaluation via $\delta^{13} C$ and atmospheric $\delta^{18} O$ analysis of tree rings. Tree Physiol. doi:10.1039/treephys/tpu067

Luis VC, Jimenez MS, Morales D, Kucera J, Wieser G (2005) Canopy transpiration of a Canary island pine forest. Agric For Meteorol 135: $117-123$

Maseyk K, Hemming D, Angert A, Leavitt SW, Yakir D (2011) Increase in water-use efficiency and underlying processes in pine forests across a precipitation gradient in the dry Mediterranean region over the past 30 years. Oecologia 167:573-585

McCarroll D, Loader NJ (2004) Stable isotopes in tree rings. Quat Sci Rev 23:771-801

McDowell N, Bond B, Dickman L, Ryan M, Whitehead D (2011) Relationships between tree height and carbon isotope discrimination. In: Meinzer FC, Lachenbruch B, Dawson TE (eds) Size- and Age-related changes in tree structure and function. Springer, Netherlands, pp 255-286

Morgan JA, Pataki DE, Korner C, Clark H, Del Grosso SJ, Grunzweig JM, Knapp AK, Mosier AR, Newton PCD, Niklaus PA, Nippert JB, Nowak RS, Parton WJ, Polley HW, Shaw MR (2004) Water 
relations in grassland and desert ecosystems exposed to elevated atmospheric $\mathrm{CO}_{2}$. Oecologia 140:11-25

Norby RJ, DeLucia EH, Gielen B, Calfapietra C, Giardina CP, King JS, Ledford J, McCarthy HR, Moore DJP, Ceulemans R, De Angelis P, Finzi AC, Karnosky DF, Kubiske ME, Lukac M, Pregitzer KS, Scarascia-Mugnozza GE, Schlesinger WH, Oren R (2005) Forest response to elevated $\mathrm{CO}_{2}$ is conserved across a broad range of productivity. Proc Natl Acad Sci U S A 102:18052-18056

Peñuelas J, Hunt JM, Ogaya R, Jump AS (2008) Twentieth century changes of tree-ring $\delta 13 \mathrm{C}$ at the southern range-edge of Fagus sylvatica: increasing water-use efficiency does not avoid the growth decline induced by warming at low altitudes. Glob Chang Biol 14: 1076-1088

Peñuelas J, Canadell JG, Ogaya R (2011) Increased water-use efficiency during the 20th century did not translate into enhanced tree growth. Glob Ecol Biogeogr 20:597-608

Rathgeber C, Nicault A, Guiot J, Keller T, Guibal F, Roche P (2000) Simulated responses of Pinus halepensis forest productivity to climatic change and $\mathrm{CO}_{2}$ increase using a statistical model. Glob Planet Chang 26:405-421

Rozas V, DeSoto L, Olano JM (2009) Sex-specific, age depedent sensitivity of tree-ring growth to climate in the deciduous tree Juniperus thurifera. New Phytol 182:687-697

Rozas V, Garcia-Gonzales I, Perez-de-Lis G (2013) Local and large-scale climatic factors controlling tree-ring growth of Pinus canariensis on an oceanic island. Clim Res 56:197-207

Sabaté S, Gracia C, Sánchez A (2002) Likely effects of climate change on growth of Quercus ilex, Pinus halepensis and Fagus sylvatica forest in the Mediterranean region. For Ecol Manag 162:23-37

Sarris D, Siegwolf R, Körner C (2013) Inter and intra-annual stable carbon and oxygen isotope signals in response to drought in Mediterranean pines. Agric For Meteorol 168:59-68

Saurer M, Siegwolf R (2007) Human impacts on tree-ring growth reconstructed from stable isotopes. In: Dawson TE, Siegwolf RTW (eds) Stable isotopes as indicators of ecological change. Academic, London, pp 49-62

Saxe H, Ds E, Heath J (1998) Trees and forest functioning in an enriched $\mathrm{CO}_{2}$ atmosphere. New Phytol 139:395-436

Seibt U, Rajabi A, Griffiths H, Berry J (2008) Carbon isotopes and water use efficiency: sense and sensitivity. Oecologia 155:441-454
Silva LCR, Anand M (2013) probing for the influence of atmospheric $\mathrm{CO}_{2}$ and climate change on forest ecosystems across biomes. Glob Ecol Biogeogr 22:83-92

Sohn JA, Gebhardt T, Ammer C, Bauhus J, Häberle K-H, Matyssek R, Grams TEE (2013) Mitigation of drought by thinning: short-term and long-term effects on growth and physiological performance of Norway spruce (Picea abies). For Ecol Manag 308:188-197

Somot S, Sevault F, Deque M, Crepon M (2008) 21st century climate change scenarios for the Mediterranean using a coupled atmosphereocean regional climate model. Glob Planet Chang 63:112-126

Srutek M, Dolezal J, Hara T (2002) Spatial structure and associations in a Pinus canariensis population at the treeline, Pico del Teide, Tenerife, Canary Islands. Arctic Alpine Res 34:201-210

Tognetti R, Cherubini P, Innes JL (2000) Comparative stem-growth rates of Mediterranean trees under background and naturally enhanced ambient $\mathrm{CO}_{2}$ concentrations. New Phytol 146:59-74

Vieira J, Campelo F, Nabais C (2009) Age-dependent responses of treering growth and intra-annual density fluctuations of Pinus pinaster to Mediterranean climate. Trees 23:257-265

Vieira J, Rossi S, Campelo F, Freitas H, Nabais C (2013) Seasonal and daily cycles of stem radial variation of Pinus pinaster in a drought prone environment. Agric For Meteorol 180:173-181

Voltas J, Camarero JJ, Carulla D, Aguilera M, Ortiz A, Ferrio JP (2013) A retrospective, dual-isotope approach reveals individual predispositions to winter-drought induced tree dieback in the southernmost distribution limit of Scots pine. Plant Cell Environ 36:1435-1448

Weigt RB, Bräunlich S, Zimmermann L, Saurer M, Grams TEE, Dietrich H-P, Siegwolf RTW, Nikolova PS (2015) Comparison of $\delta^{13} \mathrm{C}$ and $\delta^{18} \mathrm{O}$ values between tree-ring whole wood and cellulose in five species growing under two different site conditions. Rapid Commun Mass Spectrom 29:2233-2244

Wieser G, Brito P, Lorenzo JR, González-Rodríguez AM, Morales D, Jiménez MS (2016) Canary Island pine (Pinus canariemsis), an evergreen conifer in a semi-arid treeline. Progress in Botany 77, Chapter 14, in press. doi:10.1007/978-3-319-25688-7_14

Wigley TM, Briffa KR, Jones PD (1984) On the average value of correlated time series, with applications in dendroclimatology and hydrometeorology. J Clim Appl Meteorol 23:201-213

Wu CY, Hember RA, Chen JM, Kurz WA, Price DT, Boisvenue C, Gonsamo A, Ju W (2014) Accelerating forest growth enhancement due to climate and atmospheric changes in British Columbia over 1956-2001. Sci Rep 4:4461 